\title{
Persepsi dan Minat Masyarakat Terhadap Asuransi Syariah di Kabupaten Tangerang
}

\author{
Sabik Khumaini dan Muh Turizal Husein \\ Prodi Perbankan Syariah Fakultas Agama Islam Universitas Muhammadiyah Tangerang \\ Jl. Perintis Kemerdekaan I No. 33 Cikokol Tangerang \\ Email:sabik81@gmail.com,abiturizal68@gmail.com
}

\begin{abstract}
Islamic insurance is an effort to protect each other and help among a number of people through investments in the form of assets or tabarru ' which provide a pattern of taking to face certain risks or dangers through a contract that is in accordance with sharia. This study aims to determine and analyze people's perceptions and interests in Islamic insurance in Tangerang Region.

The sampling technique uses purposive sampling method. The data used are primary data obtained based on respondents' answers to the questionnaire given. This study uses multiple linear regression analysis methods with the classic assumption test, descriptive analysis, $t$ test (partial), F test (simultaneously), and coefficient test.

The results showed that partially the perception and interest variables of the community had a significant positive effect on islamic insurance. Furthermore, simultaneously the perception variable, and community interest have a significant positive effect on islamic insurance in Tangerang Region with a level of significance of less than $5 \%$.
\end{abstract}

Keywords: insurance, Islamic, perception, interest

\begin{abstract}
Abstrak
Asuransi syariah adalah usaha untuk saling melindungi dan tolong menolong diantara sejumlah orang yang melalui investasi dalam bentuk aset atau tabarru' yang memberikan pola pengambilan untuk menghadapi risiko atau bahaya tertentu melalui akad yang sesuai dengan syariah. Penelitian ini bertujuan untuk mengetahui dan menganalisis persepsi dan minat masyarakat terhadap asuransi syariah di Kabupaten Tangerang.

Teknik pengambilan sampel menggunakan metode purposive sampling. Data yang digunakan adalah data primer yang diperoleh berdasarkan jawaban responden terhadap kuesioner yang diberikan. Penelitian ini menggunakan metode analisis regresi linier berganda dengan uji asumsi klasik, analisis deskriptif, uji t (secara parsial), uji F (secara simultan), dan uji koefisien.

Hasil penelitian menunjukkan bahwa secara parsial variabel persepsi dan minat masyarakat berpengaruh positif signifikan terhadap asuransi syariah. Selanjutnya, secara simultan variabel persepsi, dan minat masyarakat berpengaruh positif signifikan terhadap asuransi syariah di Kabupaten Tangerang dengan level of significance kurang dari 5\%.
\end{abstract}

Kata kunci: Asuransi, Syariah, Persepsi, Minat

\section{PENDAHULUAN}

Pertumbuhan asuransi jiwa di Indonesia saat ini telah mengalami kemajuan yang sangat pesat. Banyaknya permintaan masyarakat terhadap kebutuhan jasa asuransi jiwa menjadi penyebab naiknya aset asuransi jiwa di Indonesia. Meningkatnya perkembangan dan pertumbuhan asuransi di Indonesia, disisi lain memunculkan adanya fatwa dari sebagian besar ulama yang mengharamkan asuransi konvensional. Sebagaian besar ulama tersebut berpendapat bahwa praktik asuransi konvensional tidak sesuai dengan prisip-prinsip syariah karena mengandung unsur gharar, maysir dan riba didalamnya. Anggapan ulama yang mengharamkan 
asuransi konvensional merupakan salah satu alasan muncul dan berkembangnya asuransi berbasis syariah. Asuransi syariah didirikan agar masyarakat Indonesia dapat berasuransi sesuai dengan ketentuan prinsip-prinsip Islam. Masyarakat Indonesia yang mayoritas penduduknya muslim menjadi salah satu faktor penyebab besarnya peluang bagi asuransi syariah (Sula:2004).

Fatwa Dewan Syariah Nasional Majelis Ulama Indonesia (DSN-MUI) tentang pedoman umum asuransi berdasarkan prinsip-prinsip syariah, memberikan definisi tentang asuransi yang berdasarkan prinsip-prinsip syariah. Asuransi Syariah ialah usaha saling tolong menolong dan melindungi anggota atau peserta asuransi melalui investasi dalam bentuk aset dan tabarru' yang memberikan pola pengembalian untuk menghadapi risiko tertentu melalui akad yang sesuai dengan prinsip-prinsip syariah. Asuransi syariah merupakan suatu cara dalam mengelola risiko yang dimungkinkan datang yang sesuai dengan syariat dan saling tolong menolong (Iqbal, 2005)

Dari pengertian di atas menjelaskan bahwa asuransi syariah merupakan asuransi bersifat saling tolong menolong dan saling melindungi yang disebut dengan ta'awun yaitu prinsip hidup saling tolong menolong dan saling melindungi atas dasar prinsipprinsip syariah dan ukhuwah islamiah antara sesama anggota peserta asuransi syariah dalam menghadapi risiko. Oleh sebab itu, premi pada Asuransi Syariah adalah sejumlah dana yang dibayarkan oleh peserta yang terdiri atas dana tabarru' dan dana tabungan. Dana tabarru' adalah dana kebijakan yang diberikan oleh peserta atau anggota asuransi dan dana tersebut akan dipergunakan untuk membayar klaim atau manfaat asuransi. Sedangkan, dana tabungan yaitu dana titipan yang disetor oleh peserta asuransi syariah selajutnya dana tersebut akan mendapat alokasi bagi hasil atau mudharabah dari pendapatan investasi yang diperoleh setiap tahun. Dana tabungan beserta alokasi bagi hasil akan dikembalikan kepada peserta asuransi syariah apabila peserta yang bersangkutan mengajukan klaim, baik berupa klaim nilai tunai maupun klaim manfaat asuransi. (Hartono:2008).
Masyarakat beranggapan berasuransi di asuransi syariah memerlukan prosedur yang rumit, hingga menimbulkan kegelisahan publik terkait penerapan sistem pengelolaan syariah tidak sesuai dengan syariah islam, sehingga memunculkan tuduhan bahwa asuransi berbasis syariah hanya berlabel syariah saja sedangkan isinya atau kegiatan operasionalnya sama saja dengan asuransi konvensional.

Asuransi syariah sudah sejak lama menjadi objek studi yang menarik, diantara penelitian tentang asuransi syariah yang dilakukan oleh T Zulaechah (2012) yang berjudul "Analisis Faktor-Faktor Minat Nasabah Memilih Asuransi Syariah (Studi pada Nasabah AJB Bumiputera 1912 Cabang Syariah Semarang)" Keberhasilan sistem dalam asuransi syariah hingga sekarang ini karena didukung oleh kwalitas dan pelayanan yang diberikan oleh perusahaan tersebut. Faktorfaktor masyarakat dalam menggunakan jasa layanan asuransi adalah pendapatan, produk, lokasi, pelayanan, dan promosi. Faktor lain yang mendorong seseorang berminat menjadi nasabah pada sebuah asuransi adalah reputasi. Suatu lembaga yang mempunyai reputasi yang baik akan dipercaya oleh nasabahnya. Sebuah lembaga dipandang mempunyai reputasi apabila lembaga itu diakui dan dipercaya sebagai perusahaan jasa dengan nama baiknya di mata masyarakat.

M. Pudail (2005) dalam penelitiannya yang berjudul “Respon Masyarakat Terhadap Asuransi Takaful (Studi Kasus pada Bekas Nasabah Askes Fulmedicare PNS Pemkot Yogyakarta). Hasil penelitian yang diperoleh menunjukan bahwa pengolaan Akses Filmedicare yang terjalin antara Takaful dan Pemkot Yogyakarta berupa ruang lingkup Askes Fulmedicare meliputi pemeliharaan kesehatan bagi seluruh PNS di lingkungan Pemkot Yogyakarta yang meliputi rawat jalan, rawat inap, dan lain-lain. Respon masyarakat Pemkot terhadap manfaat Askes Fulmedicare bersifat positif. Sedangkan tingkat minat masyarakat PNS Pemkot terhadap asuransi Takaful setelah menggunakan Askes Filmedicare adalah diketahui rata-rata tidak seimbang.

Edi Hariyadi dan Abdi Triyanto (2017) dalam penelitiannya yang berjudul "Peran Agen Asuransi Syariah Dalam Meningkatkan Pemahaman Masyarakat Tentang Asuransi 
Syariah" dapat disimpulkan bahwa peran agen asuransi syariah diantaranya sebagai akses jembatan informasi kepada masyarakat tentang asuransi syariah, yaitu pusat informasi bagi masyarakat mengenai asuransi syariah dan produk-produk asuransi syariah. Oleh karena seorang agen asuransi syariah merupakan orang kepercayaan dari perusahaan, seorang agen asuransi syariah berperan sebagai penjaga citra perusahaan asuransi syariah di mata masyarakat.

\section{TINJAUAN PUSTAKA}

Asuransi adalah perjanjian antara dua pihak atau lebih, dengan mana pihak penanggung mengikatkan diri kepada tertanggung, dengan menerima premi asuransi, untuk memberikan pergantian kepada tertanggung karena kerugian, kerusakan atau kehilangan keuntungan yang diharapkan atau tanggung jawab hukum pihak ketiga yang mungkin aka diderita tertanggung, yang timbul dari suatu peristiwa yang tidak pasti, atau memberikan suatu pembiayaan yang didasarkan atas meninggal atau hidupnya seseorang yang di pertanggungkan. Asuransi adalah suatu perjanjian, dengan mana seorang penanggung mengikat diri pada tertanggung dengan menerima suatu premi, untuk memberi penggantian kepadanya karena suatu kerugian, kerusakan atau kehilangan keuntungan yang diharapkan, yang mungkin akan dideritanya karena suatu peristiwa yang tidak tertentu (Ganie:2011).

Asuransi syariah menurut Dewan Syariah Nasional No.21/DSNMUI/X/2001 adalah usaha untuk saling melindungi dan tolong menolong diantara sejumlah orang yang melalui investasi dalam bentuk aset dan atau tabarru' yang memberikan pola pengambilan untuk menghadapi risiko atau bahaya tertentu melalui akad yang sesuai dengan syariah (dewi:2004). Prinsip dasar asuransi syariah ada sembilan macam yaitu tauhid, keadilan, tolong menolong, kerja sama, amanah, kerelaan, kebenaran, larangan riba, larangan judi (maisir) dan larangan gharar (Ali:2004)

Kemajuan dalam perkembangan industri syariah masih kalah jauh dibandingkan dengan industri konvensional, itu dikarenakan kurang minat masyarakat terhadap produk-produkjasa asuransi syariah. Rendahnya penegetahuan dan minat masyarakat dalam menggunakan produk asuransi syariah disebabkan masih kurangnya pemahaman masyarakat mengenai produk asuransi syariah dan mikanismenya. Dengan tingkat kesejahteraan penduduk yang kurang merata sangat wajar bila asuransi syariah tidak menjadi prioritas dalam pengambilan keputusan berasuransi.

Faktor-faktor yang mempengaruhi minat masyarakat dalam berasuransi syariah yaitu, pendapatan, produk, lokasi, pelayanan, dan promosi. Termasuk juga didalamnya religius stimuli yang merupakan faktor pengetahuan dan pengalaman keberagaman yang mendorong seseorang umtuk memilih asuransi syariah. Fakor lain yang mendorong seseorang berminat menjadi nasabah adalah reputasi. Selain reputasi, faktor lain yang mendorong seseorang merminat menjadi nasabah yaitu proteksi yaitu sebagai cover atau pegangan apabila dia tidak bisa menghasilkan lagi penghasilan yang seperti biasanya karena sakit, pensiun, meninggal dunia dan cacat permanen. Faktor yang terakhir yaitu investasi, selain ingin mendapatkan dana ketika sakit nasabah juga ingin mendapatkan keuntungan lain yaitu mendapatkan uang dari setiap premi yang dibayarkan perbulannya.

Pada dasarnya perusahaan asuransi dalam kegiatannya, secara terbuka mengadakan penawaran atau menawarkan sesuatu perlindungan atau proteksi serta harapan pada masa yang akan datang kepada individu atau kelompok yang ada dalam masyarakat atau institusi yang kemungkinan menghadapi kerugian lebih lanjut karena terjadinya peristiwa yang tidak tertentu atau belum pasti. Disamping itu, perusahaan asuransi juga memberikan jaminan atas terpenuhinya pendapatan seseorang, karena tepat dimana yang bersangkutan bekerja tetap terjamin kelangsungan kehidupannya. Dengan demikian, dapat dikatakan kehadiran perusahaan asuransi dalam masyarakat itu jauh lebih bermanfaat semua pihak dibandingkan dengan ketidak hadirannya (Hartono:2008).

\section{METODE PENELITIAN}

\section{Jenis dan Sumber Data Penelitian}

Penelitian yang dilakukan adalah penelitian lapangan (field research), dengan 
menggunakan pendekatan kuantitatif. Dalam penelitian ini pembahasan akan menitik beratkan pada bagaimana persepsi dan minat masyarakat terhadap asuransi syariah di Tangerang. Adapun sumber data dalam penelitian ini adalah data primer yang diperoleh dari responden yang ada di Kabupaten Tangerang.

\section{Metode Pengumpulan Data}

Teknik pengumpulan data dilakukan dengan menyebarkan kuisioner kepada responden yang tersebar di Kabupaten Tangerang dan metode wawancara dengan pihak-pihak yang berwenang dalam memberikan informasi terkait dengan penilitian ini.

\section{Metode Analisis Data}

\section{Analisis Regresi Linier Berganda}

Penelitian ini mencari pengaruh persepsi dan minat masyarakat terhadap asuransi syariah maka analisis yang digunakan adalah Regresi Linier Berganda dengan rumus sebagai berikut:

$$
Y=a+\beta 1 X_{1}+\beta 2 X_{2}+e
$$

Dimana :

$\mathrm{Y}=$ Asuransi Syariah

$\alpha=$ Konstanta

$\mathrm{X}_{1}=$ Persepsi Masyarakat

$\mathrm{X}_{2}=$ Minat Masyarakat

$\beta=$ Koefisien regresi variabel independen

e $=$ Standard eror

Teknik analisis yang digunakan adalah regresi berganda dengan persamaan kuadrat terkecil dan uji hipotesis menggunakan t-statistik untuk menguji koefisien regresi parsial serta f-statistik untuk menguji keberartian pengaruh secara bersama-sama dengan level of significance 5\% (Ghozali: 2013). Selain itu juga dilakukan uji validitas, uji reliabilitas dan uji asumsi klasik yang meliputi uji normalitas, uji multikolinieritas dan uji heteroskedastisitas.

HASIL PENELITIAN DAN PEMBAHASAN Uji Validitas dan Reliabilitas

Uji signifikansi dilakukan dengan membandingkkan nilai $\mathrm{r}_{\text {hitung }}$ (nilai Corrected
Item - Total Correlation) dengan nilai r-tabel untuk degree of freedom (df) $=\mathrm{n}-2=90-2=$ 88. dengan alpha $=0,05$ didapat $r_{\text {tabel }}$ dengan uji dua sisi $=0,207$. Jika $r_{\text {hitung }}$ lebih besar dari $r_{\text {tabel }}$ dan bernilai positif, maka butir pertanyaan tersebut dinyatakan valid (Ghozali, 2013). Hasil uji validitas dan uji reliabelitas pada pertanyaan-pertanyaan penelitian ini terdapat pada tabel berikut:

Tabel 1. Hasil Uji Validitas

\begin{tabular}{lcccc}
\hline \multicolumn{1}{c}{ Variabel } & $\begin{array}{c}\text { Butir } \\
\text { Pertanyaan }\end{array}$ & r-hitung & r-tabel & Kriteria \\
\hline Persepsi (X1) & X1.1 & 0,655 & 0,207 & Valid \\
& X1.2 & 0.641 & 0,207 & Valid \\
& X1.3 & 0,391 & 0,207 & Valid \\
& X1.4 & 0,691 & 0,207 & Valid \\
& X1.5 & 0,486 & 0,207 & Valid \\
Minat & X2.1 & 0,840 & 0,207 & Valid \\
Masyarakat & X2.2 & 0,886 & 0,207 & Valid \\
(X2) & X2.3 & 0,809 & 0,207 & Valid \\
& X2.4 & 0,829 & 0,207 & Valid \\
Asuransi & X2.5 & 0,796 & 0,207 & \\
Syariah (Y) & Y1 & 0,706 & 0,207 & Valid \\
& Y2 & 0,644 & 0,207 & Valid \\
& Y3 & 0,849 & 0,207 & Valid \\
& Y4 & 0,798 & 0,207 & Valid \\
& Y5 & 0,772 & 0,207 & Valid \\
\hline
\end{tabular}

Sumber: data primer diolah (2019)

Tabel 2. Hasil Uji Reliabilitas

\begin{tabular}{lccc}
\hline \multicolumn{1}{c}{ Variabel } & $\begin{array}{c}\text { Cronbach's } \\
\text { alpha }\end{array}$ & Cut-off & Kriteria \\
\hline Persepsi (X1) & 0,731 & 0,60 & Reliabel \\
Minat (X2) & 0,888 & 0,60 & Reliabel \\
Asuransi Syariah (Y) & 0,843 & 0,60 & Reliabel \\
\hline
\end{tabular}

Sumber: data primer diolah (2019)

Berdasarkan olah data SPSS diketahui semua variabel nilai Cronbach Alphanya di atas 0,6 . Hal ini berarti semua konsep pengukuran masing-masing variabel dalam kuesioner adalah reliabel. Artinya, jawaban seseorang terhadap pernyataan adalah konsisten atau stabil dari waktu ke waktu sehingga selanjutnya item-item pada masing-masing konsep variabel tersebut layak digunakan sebagai alat ukur pada penelitian ini.

\section{Uji Normalitas}

Model regresi yang baik adalah memiliki distribusi data normal atau mendekati normal. Uji normalitas ini dilakukan karena data 
yang diuji dengan statistik parametrik harus berdistribusi normal. Uji normalitas dapat dilakukan dengan menggunakan uji normalitas Kolmogorov Smirnov (Ghozali, 2013). Hasil uji Kolmogorov Smirnov dapat dilihat pada tabel 3 berikut ini:

Tabel 3. Uji Normalitas

One-Sample Kolmogorov-Smirnov Test Unstandardized Residual

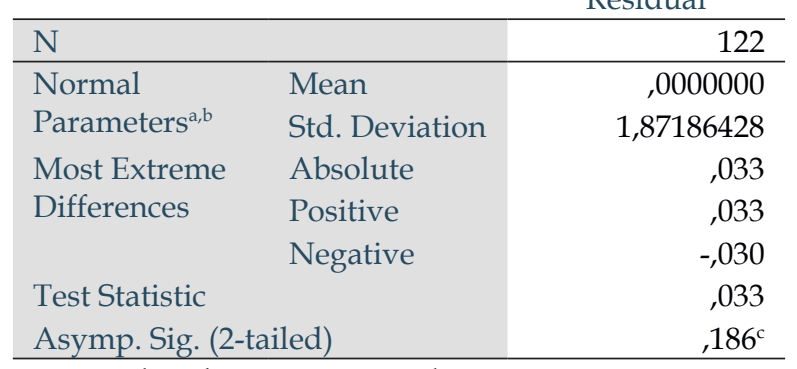

a. Test distribution is Normal.

b. Calculated from data.

c. Lilliefors Significance Correction.

Sumber: data sekunder yang diolah

Hasil pengujian terhadap normalitas dengan menggunakan uji Kolmogorov Smirnov menunjukkan nilai residual statistic mempunyai nilai signifikansi diatas 0,05 yaitu sebesar 0,186 , hal ini berarti data yang ada terdistribusi normal.

Deteksi yang lain dengan melihat penyebaran titik-titik pada sumbu diagonal dari grafik melalui grafik normal P-P Plot. Berdasarkan grafik normal P-P Plot terlihat titik-titik pada grafik

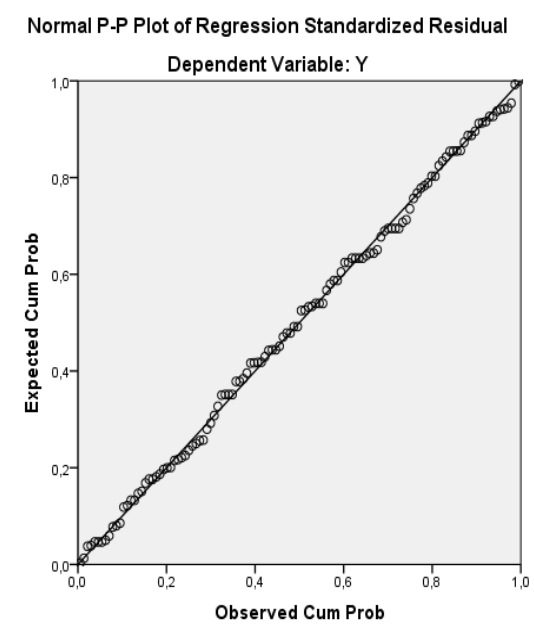

Sumber: data sekunder yang diolah

Gambar 1. Uji Normalitas dengan Grafik P-P Plot masih menyebar disekitar garis diagonal, serta penyebarannya mengikuti arah garis diagonal. Hasil tersebut menunjukkan bahwa data penelitian terdistribusi secara normal. Grafik P-P Plot dapat dilihat pada gambar 1 .

\section{Uji Heteroskedatisitas}

Pengujian heteroskedastisitas dilakukan dengan menggunakan Scatterplot. Pola Scatterplot yang tidak membentuk garis atau bergelombang menunjukkan tidak adanya masalah heteroskedastisitas. Hasil pengujian heteroskedastisitas dapat dilihat pada gambar 2 sebagai berikut:

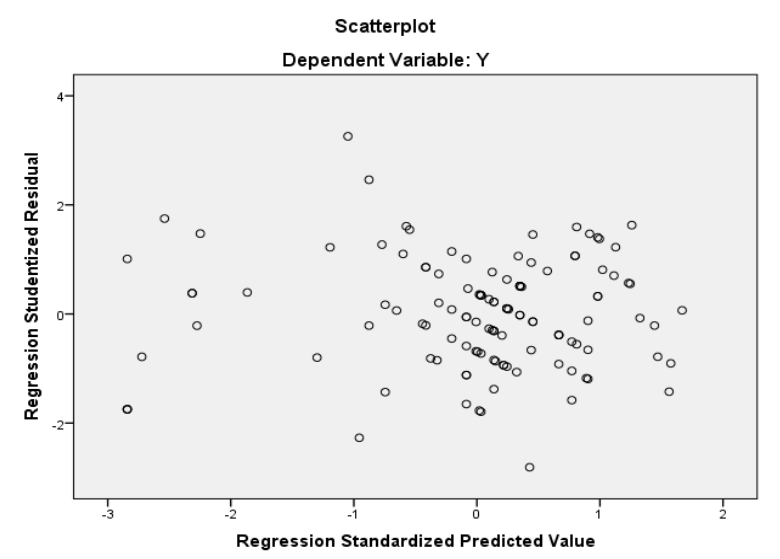

Sumber: data sekunder yang diolah

Gambar 2. Uji Heteroskedastisitas

Pada gambar 2 grafik scatterplot terlihat titik-titik menyebar secara acak tidak membentuk sebuh pola tertentu yang jelas serta tersebar baik diatas maupun dibawah angka nol pada sumbu y. Hal ini berarti tidak terjadi heteroskedastisitas pada model regresi sehingga model regresi layak dipakai untuk melihat pengaruh variabel independen terhadap variabel dependen.

\section{Uji Multikolinieritas}

Uji multikolinearitas dapat dilakukan dengan melihat nilai VIF (variance inflation factor) dan Tolerance dari output regresi. Nilai VIF (variance inflation factor) yang lebih dari 10 atau Tolerance yang lebih kecil dari 0,1 menunjukkan adanya gejala multikolinearitas dalam model regresi. Nilai VIF (variance inflation factor) dan Tolerance dari masingmasing variable independen dapat dilihat pada Tabel 4. 
Tabel 4. Uji Multikolinearitas

\begin{tabular}{|c|c|c|c|}
\hline \multicolumn{4}{|c|}{ Coefficients $^{a}$} \\
\hline \multicolumn{2}{|c|}{ Model } & \multicolumn{2}{|c|}{ Collinearity Statistics } \\
\hline & Tolerance & VIF & \\
\hline \multirow[t]{2}{*}{1} & $\mathrm{X} 1$ & ,956 & 1,283 \\
\hline & $X 2$ & ,838 & 1,194 \\
\hline
\end{tabular}

a. Dependent Variable: $Y$

Sumber: data sekunder yang diolah

Berdasarkan hasil pada Tabel 4 dapat dijelaskan bahwa nilai VIF (variance inflation factor) dibawah 10 dan nilai tolerance di atas 0,1. Jadi dapat disimpulkan bahwa model regresi terbebas dari masalah multikolinearitas.

\section{Uji Koefisien Determinasi $\left(\mathbf{R}^{2}\right)$}

Koefisien determinasi $\left(\mathrm{R}^{2}\right)$ pada intinya untuk mengukur seberapa jauh kemampuan model dalam menerangkan variasi variabel dependen/tidak bebas. Nilai koefisien determinasi adalah antara nol (0) dan satu (1). Nilai $R^{2}$ yang kecil berarti kemampuan variabel-variabel independen (bebas) dalam menjelaskan variasi variabel dependen amat terbatas. Nilai yang mendekati satu berarti variabel-variabel independen memberikan hampir semua informasi yang dibutuhkan untuk memprediksi variasi variabel dependen (Ghozali, 2013).

Dilihat dari Tabel 5, nilai koefisien determinasi (adjusted $\mathrm{R}^{2}$ ) sebesar 0,562 atau $56,2 \%$. Hal ini menjelaskan bahwa kemampuan untuk menjelaskan variabel independen yaitu persepsi dan minat masyarkat terhadap variabel dependen yaitu asuransi syariah yang mana bisa dijelaskan oleh model persamaan sebesar $56,2 \%$ sedangkan selisihnya sebesar $43,8 \%$ dipengaruhi oleh faktor lain yang tidak dimasukkan dalam model regresi.

\section{Uji Statistik F}

Uji F dilakukan untuk mengetahui apakah semua variabel independen atau bebas yang dimasukkan dalam model mempunyai pengaruh secara bersama-sama terhadap variabel dependen, untuk mengetahuinya dilakukan dengan membandingkan nilai $\mathrm{F}_{\text {hituns }}$ dengan $F_{\text {tabel }}$ dan melihat nilai signifikansi level seperti ditunjukkan pada Tabel 6 .

Dari hasil perhitungan pada tabel 6, hasil uji $\mathrm{F}$ dapat di lihat dari nilai $\mathrm{F}_{\text {hitung }}$ pada tabel ANOVA yaitu diperoleh $\mathrm{F}_{\text {hitung }} 78,730$ dengan tingkat signifikansi lebih kecil dari 0,05 dan $\mathrm{F}_{\text {hitung }}>\mathrm{F}_{\text {tabel }}(78,730>3,10)$, maka model layak (goodness of fit).

\section{Uji Statistik $\mathbf{t}$}

Uji t digunakan untuk menguji apakah secara parsial variabel persipsi dan minat masyarakat memberikan pengaruh yang signifikan atau tidak terhadap asuransi syariah. Hasil uji signifikansi atau uji $t$ dapat dilihat sebagai berikut:

Tabel 5. Koefisien Determinasi

Model Summary ${ }^{\mathrm{b}}$

\begin{tabular}{|c|c|c|c|c|c|}
\hline Model & $\mathrm{R}$ & R Square & Adjusted R Square & Std. Error of the Estimate & Durbin-Watson \\
\hline 1 & $755^{\mathrm{a}}$ & 570 & ,562 & 1,888 & 1,868 \\
\hline $\begin{array}{l}\text { a. Predi } \\
\text { b. Depe }\end{array}$ & $\begin{array}{l}\text { ors: }(C \\
\text { dent V }\end{array}$ & $\begin{array}{l}\text { nstant), } \mathrm{X} \\
\text { riable: } \mathrm{Y}\end{array}$ & & & \\
\hline
\end{tabular}

Tabel 6. Uji F

\begin{tabular}{llrrrrr}
\multicolumn{7}{c}{ ANOVA $^{\mathrm{a}}$} \\
\multicolumn{1}{l}{ Model } & Sum of Squares & \multicolumn{1}{c}{$\mathrm{df}$} & Mean Square & \multicolumn{1}{c}{ F } & \multicolumn{1}{c}{ Sig. } \\
\hline 1 & Regression & 560,990 & 2 & 280,495 & 78,730 &, $000^{\mathrm{b}}$ \\
& Residual & 423,969 & 119 & 3,563 & & \\
& Total & 984,959 & 121 & & & \\
\hline
\end{tabular}

a. Dependent Variable: $Y$

b. Predictors: (Constant), X2, X1

Sumber: data sekunder yang diolah 
Tabel 7. Uji t

Coefficients $^{\mathrm{a}}$

\begin{tabular}{|c|c|c|c|c|c|c|}
\hline \multirow{2}{*}{\multicolumn{2}{|c|}{ Model }} & \multicolumn{2}{|c|}{ Unstandardized Coefficients } & \multirow[t]{2}{*}{ Standardized Coefficients } & \multirow{2}{*}{$t$} & \multirow{2}{*}{ Sig. } \\
\hline & & Std. Error & Beta & & & \\
\hline \multirow[t]{3}{*}{1} & (Constant) & 6,071 & 1,083 & & 5,604 & ,009 \\
\hline & $\mathrm{X} 1$ & 227 & ,052 & 288 & 4,380 & 007 \\
\hline & $\mathrm{X} 2$ & 483 &, 054 &, 591 & 8,997 &, 000 \\
\hline
\end{tabular}

a. Dependent Variable: $Y$

Sumber: data sekunder yang diolah

Dari Tabel 7, maka dapat disusun persamaan regresi linier berganda sebagai berikut:

$$
\mathrm{ROI}=0,288 \times 1+0,591 \times 2
$$

Hasil pengujian masing-masing variabel independen terhadap variabel dependennya dapat dianalisis sebagai berikut:

1. Dari hasil perhitungan uji-t pada variabel persepsi diperoleh nilai $t$ hitung sebesar 4,380 dengan nilai signifikansi sebesar 0,004 . Karena nilai t hitung 4,380 lebih besar dari t-tabel sebesar 1,986 dan nilai signifikansi lebih kecil dari 0,05 yaitu sebesar 0,007 maka berarti ada pengaruh positif signifikan antara persepsi dengan asuransi syariah.

2. Dari hasil perhitungan uji-t pada variabel minat masyarakat diperoleh nilai t hitung sebesar 8,997 dengan nilai signifikansi sebesar 0,000. Karena nilai t hitung 8,997 lebih besar dari t-tabel sebesar 1,986 dan nilai signifikansi lebih kecil dari 0,05 yaitu sebesar 0,000 maka berarti ada pengaruh positif signifikan antara persepsi dengan asuransi syariah.

\section{KESIMPULAN DAN SARAN}

Sesuai hasil analisis data dan hasil pembahasan yang telah diuraikan maka dapat disimpulkan bahwa data yang dipergunakan dalam penelitian ini terdistribusi normal, tidak terdapat multikolinieritas dan bebas heteroskedastisitas dan berdasarkan uji koefisien determinasi (adjusted $\mathrm{R}^{2}$ ) sebesar 0,562 atau $56,2 \%$. Hal ini menjelaskan bahwa kemampuan untuk menjelaskan variabel independen yaitu persepsi dan minat masyarkat terhadap variabel dependent yaitu asuransi syariah yang mana bisa dijelaskan oleh model persamaan sebesar $56,2 \%$ sedangkan selisihnya sebesar $43,8 \%$ dipengaruhi oleh faktor lain yang tidak dimasukkan dalam model regresi.

Hasil perhitungan uji-t pada variabel persepsi diperoleh nilai thitung sebesar 4,380 dengan nilai signifikansi sebesar 0,007. Karena nilai t hitung 4,380 lebih besar dari t-tabel sebesar 1,986 dan nilai signifikansi lebih kecil dari 0,05 yaitu sebesar 0,007 maka berarti ada pengaruh positif signifikan antara persepsi dengan asuransi syariah dan hasil perhitungan uji-t pada variabel minat masyarakat diperoleh nilai t hitung sebesar 8,997 dengan nilai signifikansi sebesar 0,000 . Karena nilai thitung 8,997 lebih besar dari t-tabel sebesar 1,986 dan nilai signifikansi lebih kecil dari 0,05 yaitu sebesar 0,000 maka berarti ada pengaruh positif signifikan antara persepsi dengan asuransi syariah.

Sosialisasi tentang keberadaan asuransi syariah masih harus ditingkatkan lagi. Sosialisasi sebaiknya tidak hanya mengandalkan kemampuan tenaga agen asuransi, karena agen asuransi hanya akan melihat orang-orang yang dianggapnya potensial yang mau bergabung menjadi nasabah asuransi saja. Perlu juga menjelaskan kepada masyarakat manfaat dari asuransi syariah yang akan didapat kita menjadi nasabah asuransi syariah.

\section{DAFTAR PUSTAKA}

Ali, Hasan (2004), Asuransi Dalam Perspektif Hukum Islam, Kencana, Jakarta

Dewi, Gemala (2004), Aspek-Aspek Hukum dalam Perbankan dan Perasuransian Syariah di Indonesia, Prenada Media, Jakarta.

Fatwa Dewan Syariah Nasional No.21/DSNMUI/X/2001 Tentang Pedoman Umum Asuransi Syariah. 
Ganie, Junaidi, DKK (2011), Hukum Asuransi Indonesia, Sinar Grafika, Jakarta.

Ghozali, Imam, 2013, Aplikasi Analisis Multivariate dengan Program SPSS 21, Badan Penerbit Universitas Diponegoro, Semarang.

Hariyadi, Edi dan Triyanto, Abdi (2017) Peran Agen Asuransi Syariah Dalam Meningkatkan Pemahaman Masyarakat Tentang Asuransi Syariah Jurnal Ekonomi dan Perbankan Syariah Vol. 5. No.1, April, 2017.

Hartono, Sri rejeki (2008), Hukum Asuransi dan Perusahaan Asuransi, Sinar Grafika, Jakarta
Iqbal, M. (2005). Asuransi Umum Syariah dalam Praktik, Gema Insani Press, Jakarta. M. Pudail (2005), Respon Masyarakat Terhadap Asuransi Takaful (Studi Kasus pada Bekas Nasabah Askes Fulmedicare PNS Pemkot Yogyakarta), Tesis UII, Yogyakarta.

Sula, Mumamad Syakir (2004), Asuransi Syariah (Life and General): Konsep dan Sistem Operasional, Gema Insani Press, Jakarta.

T Zulaechah 2012. Analisis Faktor-Faktor Minat Nasabah Memilih Asuransi Syariah (Studi pada Nasabah AJB Bumiputera 1912 Cabang Syariah Semarang), Eprints Walisongo, Semarang. 